\title{
TOURIST AND RECREATIONAL POTENTIAL OF THE SALT LAKES OF WESTERN KAZAKHSTAN
}

\author{
Kazhmurat M. AKHMEDENOV* \\ M. Utemisov West Kazakhstan State University, Department of Geography, \\ N. Nazarbaeyv Ave 162, 090000 Uralsk, Kazakhstan, e-mail: kazhmurat78@mail.ru
}

\begin{abstract}
Citation: AKHMEDENOV, K.M. (2020). TOURIST AND RECREATIONAL POTENTIAL OF THE SALT LAKES OF WESTERN KAZAKHST AN. GeoJournal of Tourism and Geosites, 30(2spl), 782-787. https://doi.org/10.30892/gtg.302spl01-505
\end{abstract}

\begin{abstract}
The purpose of our research is to assess the potential and conditions for the development of health tourism based on the therapeutic mud of salt lakes of West Kazakhstan. Using classical methods of hydrological and hydrogeological research, the certification of mineral waters and therapeutic mud (raps and peloids) of the lakes Inder, Aralsor, Alzhansor, Hakisor, Sorkol, Bolshoy Sor, was carried out and the qualitative components of the raps and mud of these lakes were investigated. The analysis of the obtained data showed that a strongly sulphide salinized class of mud prevails in the two lakes studied: the Inder and the Alzhansor (Elton type). The Aralsor and Lake Hakisor are characterized by a sulphide weakly alkaline class (Karachi type). The mud of salty Lake Sorkol (Medvezhinsky type) and the Bolshoy Sor (Cheder type) belongs to the class of weakly sulphide. The expediency of sanatorium-resort and medical-health tourist use of studied salt lakes has been revealed.
\end{abstract}

Key words: lakes, raps, mud, hydromineral resources, balneology, physicochemical properties, West Kazakhstan

$* \quad * \quad * \quad * \quad * *$

\section{INTRODUCTION}

Therapeutic muds of lakes are not widespread in the world (Williams, 1996) and are commonly found locally, such as Dead Sea therapeutic muds (Kotova et al., 2016), Spain (Carretero et al., 2014), Turkey (Karakaya et al., 2010), Cuba (Margaret et al., 2018), Mongolia (Egorov, 1993; Tserenkhand et al., 2018), China (Williams, 1991), Russian Federation (Kutlusurin, 2006; Myazina, 2013a, 2013b; Fedorov and Ruban, 2018; Sallam et al., 2018; Fedorov and Ruban, 2019; Kotov et al., 2019) and Kazakhstan (Akhmedenov et al., 2015; Akhmedenov et al., 2016a; Zhensikbayeva et al., 2017; Tokpanov et al., 2019; Kan et al., 2019). Now on the territory of Kazakhstan takes place an active study of tourist and recreational potential of various parts of it (Egorina et al., 2016; Saparov and Zhensikbayeva, 2016; Zhensikbayeva et al., 2018; Yegemberdiyeva et al., 2018; Kerimbay et al., 2020). The territory of West Kazakhstan is rich with unique lakes of different genesis, which concentrate high recreational and balneological potential, but it is used poorly due to the lack of investment in this sphere and as a result due to the lack of infrastructure and advertising. Mineral lakes are a kind of surface deposits of mineral waters and mud. They include lakes whose water has a total mineralization of over $1 \mathrm{~g} / \mathrm{l}$. The waters of mineral lakes have different chemical composition in the area of the Caspian lowland containing chloride sodium composition with mineralization up to 300 and more g/l. Bottom deposits of mineral lakes are represented by silt which is used in many resorts as curative mud. Today only the Lake Inder in Atyrau region was studied in sufficient detail according to geomorphological, hydraulic-hydro chemical characteristics (Posokhov, 1948; Filonets and Omarov, 1974; Diarov et al., 1981; Akhmedenov et al., 2016b; Petrishchev and Akhmedenov, 2017; Akhmedenov, 2018). The most of the salty lakes of West Kazakhstan whose mud could potentially be considered as curative were not actually studied. It should be noted that the obtained data on physical and chemical analysis of medical mud of the salt lakes can serve as a justification for projects regarding the development of balneological infrastructure and ecological tourism in West Kazakhstan. Health tourism is a promising and popular direction of tourism in Kazakhstan. It is common to allocate climatic, mud and balneological resort resources, moreover, the resorts may have one or more natural therapeutic resources. Depending on the therapeutic properties of natural resources, resorts can specialize in a certain profile (musculoskeletal, cardiological, etc.). Health tourism is often understood as tourism for recreation and health promotion within the framework of special health programs for the treatment of a large range of body disorders and general health improvement, recovery of the body after diseases (Neumann et al., 2001; Kapiki et al., 2014; Karagülle and Karagülle, 2015; Matsumoto, 2018; Yang et al., 2018). At present, in addition to natural medical resources, the factors such as availability of the developed tourist infrastructure, application of innovative technologies and techniques, and the high qualification of personnel are becoming increasingly important for the development of medical and health tourism. The purpose of this article is to assess in detail the properties of the salt lakes peloids of West Kazakhstan in order to make recommendations on their practical use for the development of health tourism and health resort economy in the West of the Republic of Kazakhstan.

\section{MATERIALS AND METHODS}

Classical hydrological and hydrogeological approaches were used in salt lake surveys. A chemical analysis was conducted to determine the chemical composition of the lake, spring water and the mud solution. The chemical analyses were conducted at the licensed chemical and analytical research laboratory of the U. Akhmedsafin Institute of Hydrogeology and Hydrophysics (Almaty, Kazakhstan, certificate of accreditation № KZ.I.02.0782 dated 15.05.2015) and the Zhangir Khan West Kazakhstan Agrarian Technical University test center (Uralsk, Kazakhstan, certificate of accreditation № KZ.I.09.0147 dated 23.01.2017). Waters from Lake Inder, Lake Hakisor, Lake Bolshoy Sor, Lake Alzhansor, Lake Sorkol and Lake Aralsor were subjected to a hydrochemical analysis. The samples were taken at a depth of $0.3-0.5 \mathrm{~m}$ in an amount of $1 \mathrm{~L}$ in polyethylene bottles for ion composition analysis and $1 \mathrm{~L}$ in dark glass water for petroleum composition analysis. The $\mathrm{pH}$ level was measured using digital ion meters I-160M and Seven Easy pH Mettler Toledo according to the GOST 26449.1-85 state standard; the concentration of dry residue was determined by using a weight method; the concentration of trace elements was determined via appropriate methods of measurement using a Varian AA-140 atomic absorption spectrophotometer with flame atomization; the hardness and cation-ion composition was determined according to the state standard 26449.1-85. Ammonium nitrogen, nitrites and nitrates were determined via spectrophotometry using a Varian, Cary-50 device. The total content of sodium and potassium ions is determined by the calculation method. The study used navigational and cartographic hardware and software. The Garmin ETrex Vista was used to obtain coordinate data. Its elevation figures were compared to and corrected using 
SRTM radar mapping data. As a result of the field and laboratory researches in 2015-20196 promising balneological sites were studied the Lakes Inder, the Alzhansor, the Aralsor, the Hakisor, the Sorkol, the Bolshoy Sor (Figure 1). The results of chemical analyses of the mud from these lakes have been compared with the existing classification of medical muds (Razumov et al., 2000). Salty lakes with medical mud are located in various natural zones and geomorphological areas of West Kazakhstan. Out the six salt lakes studied there are five lakes geomorphologically located within the Caspian lowland (the Inder, the Alzhansor, the Aralsor, the Hakisor, the Bolshoy Sor) and one lake Sorkol is located on the Podural Plateau. In landscape terms, the three lakes (the Bolshoy Sor, the Alzhansor, the Sorkol) are located in the dry-steppe zone, one Lake Aralsor in the semi-desert zone, and the two lakes (the Hakisor, the Inder) in the desert zone.

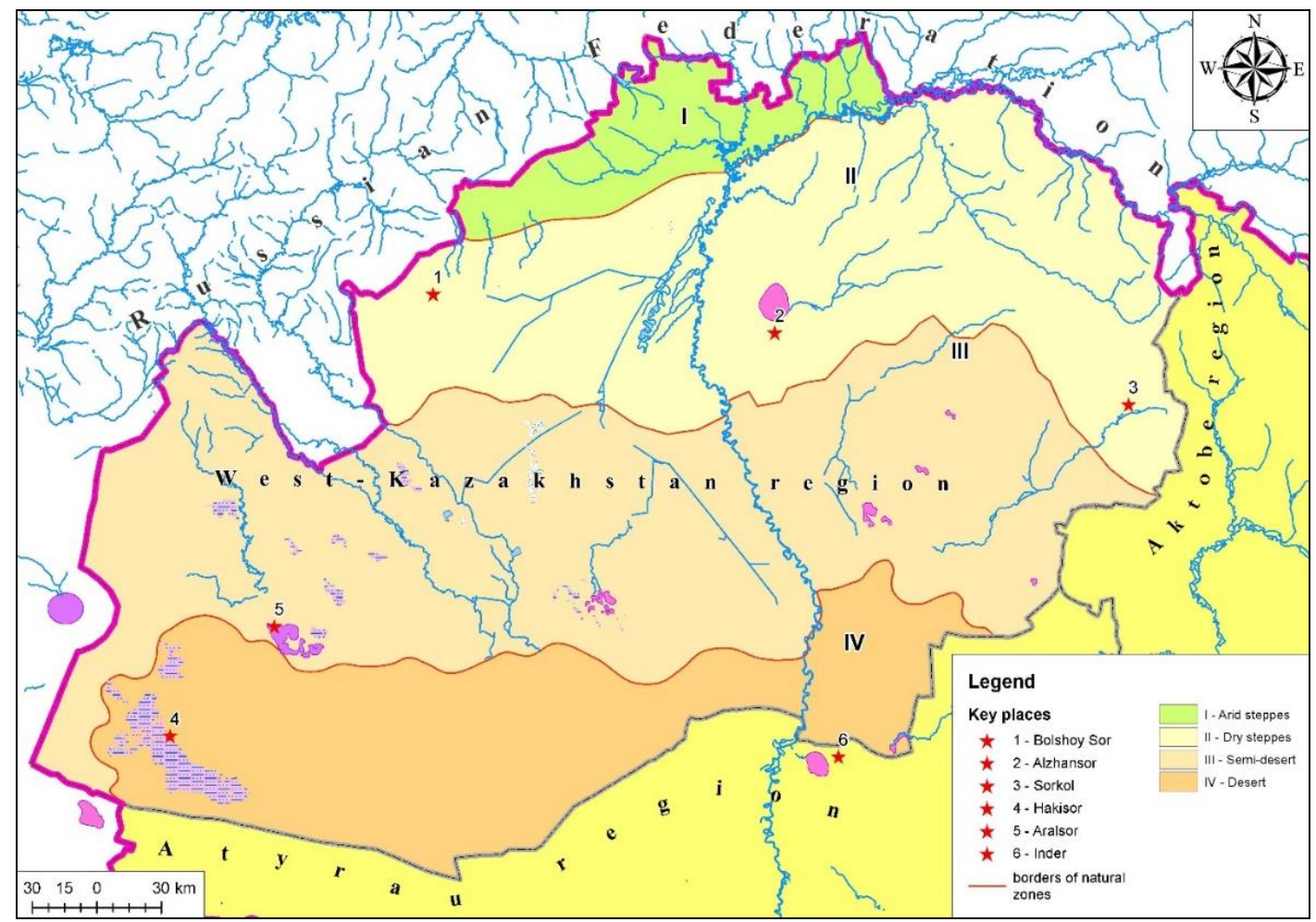

Figure 1. Location of the studied mud lakes

\section{RESULTS DISCUSSIONS}

Lake Bolshoy Sor is located in Mereken rural area of Taskalinsky district of West Kazakhstan region in $7 \mathrm{~km}$ to the south-east from Bogatyrevo-Taskala road, an area with adjacent territories of 1 thousand. The lake Bolshoy Sor has a round shape with cliff banks up to 4-5 meters and with a diameter of about $2.5 \mathrm{~km}$. The Bolshoy Sor is covered with salt crust under which there is a layer of dirt. In rainy years the central part of the lake pit is under the water (Figure 2). Balneological interest has Lake Alzhansor located in $22 \mathrm{~km}$ to the south from the Lake Shalkar. Its size is $1.5 \times 1.5 \mathrm{~km}$. The banks are steep cliff, their height ranges from 2 to 5-7 meters. The water in the lake is salty and appears early in spring and in rainy years in the central part. The rapa mainly comes to the surface (Figure 2). In origin, the lake has a saltwater negative structure. A small drying river flows into the northeast part of the lake which is enclosed by dambs. The water in this river is salty till the dam and behind the dam is fresh. The lake has balneological significance and the local population considers it as a holy place. According to the resolution of the Government of the Republic of Kazakhstan No. 932 dated September 28, 2006 the Lake Alzhans or was included in the list of objects representing a state natural reserve fund of the republican significance. The lake is situated in $10 \mathrm{~km}$ to the East from the Douana aul. The area is about 20 hectares at the territory of Shalkar rural area of Terektinsky district in West Kazakhstan.

The lake Sorkol is located in the Almaznen rural area of Shyngyrlau district in the West Kazakhstan region in $3.5 \mathrm{~km}$ north-east from the Sorkol village and $16 \mathrm{~km}$ to the north-west from the Almaz village. In landscape relation it occupies the hilly sandy-steppe plain of the Podural plateau. Its size is $2.1 \times 1.6 \mathrm{~km}$. The area is about 750 hectares. The Sorkol Lake has shallow water banks overgrown by reeds-cane vegetation (Figure 2). The lake's southern coastal lowlands are occupied by the numerous saltwater and dry ducts covered with salt crust and rare saltwater vegetation. The northern and north-western parts of the lake are sandy with islets and shallow water ducts.

There are two lakes with mud on the territory of Bokeyordinsky district of the West Kazakhstan region: Lake Hakisor and Lake Aralsor. Lake Hakisor is an extensive downhill filled with black and brown mud to some depth and from the surface has the appearance of a tacyric plain. The Hakisor starts in $4 \mathrm{~km}$ south from the Khan Ordasa village and stretches to the south-west direction. The length of the Hakisor is $65-75 \mathrm{~km}$ with the width varies from 2 to $15 \mathrm{~km}$ and the total area of $300-400 \mathrm{~km}^{2}$. The waters of rivers, ravines and beams flow from the surrounding steppes into the Hakisor Valley and groundwater (Figure 2) comes out in its bottom as well. The largest of the lakes studied is Lake Aralsor, with an area of 10.000 hectares. The width of the lake ranges from 3 to 8 kilometres. It is drainless. Bitter-salt water reserves are replenished by atmospheric precipitation and the river. The bottom is flat and filled with salt and fine water lenses (Figure 2). The lake itself has a sickle shape, the banks are steep, cliff-like and in some places their height reaches 6-7 meters. The mud of the Inder springs comes out on the northern shore of Lake Inder, which is located in $150 \mathrm{~km}$ north from Atyrau on the left bank of the Ural River in the Inder district of Atyrau region. Inder sources belong to the category of therapeutic mineral waters and were described in the articles of the author (Akhmedenov et al., 2015; Petrishchev and Akhmedenov, 2017; Akhmedenov, 2018) providing a full analysis of their waters. Minor deposits of black sludge are observed at the exit site of all sources as well as on the banks of the lake itself. However, only the mud deposits situated along the channel of the largest source Aschytusbulak have a practical interest. This source has an average rate of $30 \mathrm{l} / \mathrm{s}$. Its water belongs to the type of salt brine (total mineralization is $46 \mathrm{t} / \mathrm{l}$ ). Aschytusbulak exits the karst funnel and then flows through the deep valley covered on all sides of the winds. Due to the good warming of the bottom of this valley, the mineral mud was formed along the both banks of the Aschytusbulak stream (Figure 2). 

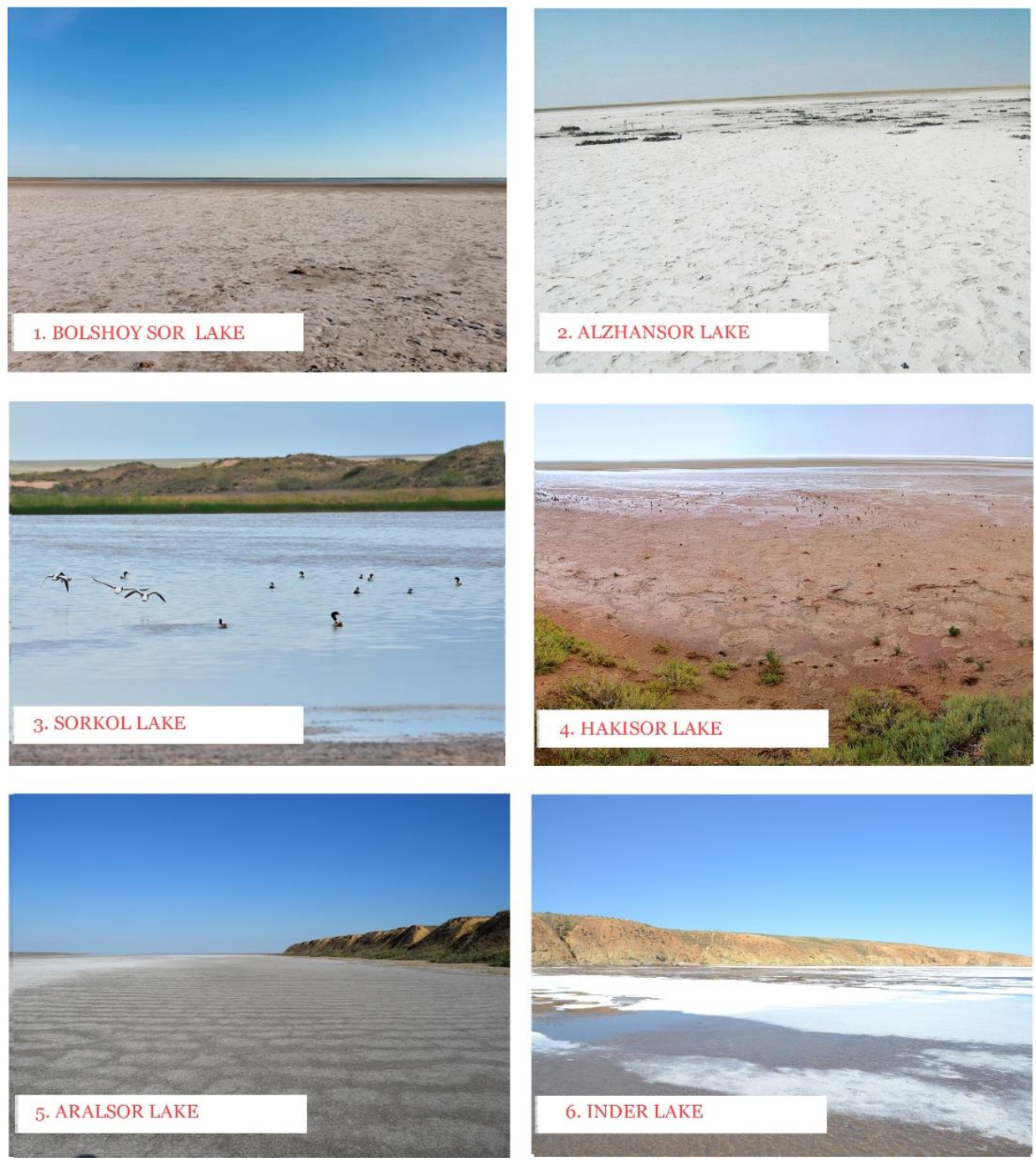

Figure 2. The studied mud lakes of the Western Kazakhstan

This mud is widely known among the local population. In summer patients come here not only from villages, but also from cities. Usually small recesses are dug out on the clay banks of the source and filled with liquid black mud. The baths prepared in such a way are used for the mud treatment. The bottom of the valley is full of this kind of indentations. The actual material accumulated during the research shows that the therapeutic mud of the salty lakes of West Kazakhstan is similar to the known types of therapeutic mud traditional in Russia and the near abroad (Rudenko, 1975; Kutlusurin, 2006; Belenitskaya, 2013; Kotov et al., 2019; Fedorov and Ruban, 2019). Studies showed that according to the classification of therapeutic muds the most valuable sulphidic and silt bromic peloida belonging to the following classes - strong sulphide, sulphide, weak sulphide, to saline subclasses and highly mineralized are widespread in the Western Kazakhstan (Table 1). In comparison with the known mud bath resorts, the mud of Lake Inder and Lake Alzhansor correspond to the Elton variety - by the name of the lake existing in the Volgograd region in Russian Federation (Akhmedenov et al., 2016b; Akhmedenov, 2018).

The mud of Lake Hakisor and Aralsor correspond to the Karachinsky variety - by the name of the lake existing in Novosibirsk region in Russian Federation. According to the results of the research the mud of Lake Bolshoy Sor corresponds to the Chederskoe variety and is classified as a type of highly mineralized average sulphide sludge mud. Lake Cheder is located in $45 \mathrm{~km}$ south-east from Kyzyl city in the Republic of Tyva in Russian Federation. The mud of Lake Sorkol corresponds to the Medvezhinsky variety - by the name of the lake existing in the Stavropol region in Russian Federation and belongs to the class of weakly sulphide and subclass of weakly alkaline.

The highest mineralization is in Lake Inder (326 g/l), then in Lake Aralsor (257 g/l), Sorkol (195 g/l) and Hakisor (160 g/l). The mineralization of Lake Alzhansor is $152 \mathrm{~g} / \mathrm{l}$ and in Lake Bolshoy Sor - $124 \mathrm{~g} / \mathrm{l}$. The mineralization of Lake Inder is comparable to the world's counterparts. For example, the mineralization of the widely known Dead Sea is 280-300 g/l, while the mineralization of the brine lakes Assal and Juliet, having a salt structure of the Danakil Valley, located within the Circumaravian salt ring of the Afro-Arabian rift system exceeds $350 \mathrm{~g} / \mathrm{l}$ and reaching $90 \% \mathrm{~g} / \mathrm{l}$ in the lakes with the highest magnesium content (up to 400-460). For comparison: a mineralization of mud of Lake Tambukan in Caucasus mineral waters is $60 \mathrm{~g} / \mathrm{l}$, a sludge mud of Lake Saki is $29.5 \mathrm{~g} / \mathrm{l}$ and Anapa sludge sulphide mud is $31.5 \mathrm{~g} / \mathrm{l}$.

Mud solutions of Lake Inder, Lake Aralsor, Lake Hakisor refer to chloride-sodium, Lakes Alzhansor and Bolshoy Sor to chloride-sodiummagnesium, and Lakes Sorkol to chloride-sulphate-sodium types. A very important property of mud and raps is their high alkalinity, which prevents mud from falling out of gypsum sediment than the Hakisor and Aralsor lakes are advantageously different from other treatment lakes, such as the Tambukan. These features cause high therapeutic properties of their mud and put it in line with the best therapeutic dirt of domestic and foreign resorts. The therapeutic mud of Lake Inder in Atyrau region is a black mud of a dense consistency and non-uniform structure, well majors and is attached to the body with a smell of wet bitumen. Scientists (Tatarinov, 1938; Mocrinsky, 1938; Korobov and Polenov, 1964; Eisenstadt et al., 1967) refer the time of its occurrence to the Jurassic period. Along with minerals, the black mud is extre mely rich in humus and enzymes that are very useful for human health. Hormonal substances formed as a product of decomposition of plants, insects and even birds (biologically active humus) are present in its composition. The insects that fall into the salty lake cannot take off back, fall asleep, 
gradually decompose and turn into dirt. According to their structure, the peloids consist of a solid part, colloids and mud solution filling the spaces between the solid part. The mud solution impregnated the colloidal complex and adsorbed its ions on it (Table 1).

Table 1. Composition of the tested sulphide-sludge peloids of West Kazakhstan in accordance with the classification of therapeutic mud Data source: (personal original data, and also Akhmedenov et al., 2016a; Akhmedenov, 2019)

\begin{tabular}{|c|c|c|c|c|c|c|c|c|c|}
\hline $\begin{array}{c}\text { Mineralization, } \\
\mathrm{g} / \mathrm{l}\end{array}$ & $\begin{array}{c}\text { FeS, \% from } \\
\text { natures substances }\end{array}$ & $\mathrm{H} 2 \mathrm{~S}$, in weight $\%$ & $\mathrm{pH}$ & Eh, $\mathrm{mB}$ & $\mathrm{Br}, \mathrm{mg} / \mathrm{l}$ & $\mathrm{J}, \mathrm{mg} / \mathrm{l}$ & $\begin{array}{c}\text { Thermal capacity, } \\
\text { cal/g.grad }\end{array}$ & $\begin{array}{c}\text { Class, } \\
\text { subclass }\end{array}$ & $\begin{array}{c}\text { Name of } \\
\text { analogs }\end{array}$ \\
\hline \multicolumn{10}{|c|}{ Lake Inder } \\
\hline 326 & 0.55 & 0.3 & 7.0 & 263 & 40.8 & 1.8 & 0.76 & $\begin{array}{l}\text { Strong sulphide, } \\
\text { weakly alkaline }\end{array}$ & Elton \\
\hline \multicolumn{10}{|c|}{ Lake Alzhansor } \\
\hline 152 & 0.56 & 0.1 & 7.9 & 310 & 104.3 & 0.1 & 0.84 & $\begin{array}{l}\text { Strong sulphide, } \\
\text { weakly alkaline }\end{array}$ & Elton \\
\hline \multicolumn{10}{|c|}{ Lake Hakisor } \\
\hline 160 & 0.15 & 0.01 & 7.2 & 148 & 120.8 & 0.1 & 0.69 & $\begin{array}{c}\text { Sulphide, } \\
\text { weakly alkaline }\end{array}$ & Karachi \\
\hline \multicolumn{10}{|c|}{ Lake Aralsor } \\
\hline 256 & 0.47 & 0.03 & 8.4 & 231 & 87.9 & 0.7 & 0.82 & $\begin{array}{c}\text { Sulphide, } \\
\text { weakly alkaline }\end{array}$ & Karachi \\
\hline \multicolumn{10}{|c|}{ Lake Sorkol } \\
\hline 195 & 0.11 & 0.02 & 9.0 & 394 & 139.4 & 0.1 & 0.79 & $\begin{array}{l}\text { Weak sulphide, } \\
\text { weakly alkaline }\end{array}$ & Medvezhinsky \\
\hline 124 & 0.32 & 0.04 & 7.6 & 268 & 123.8 & 0.1 & 0.85 & $\begin{array}{c}\text { Weak sulphide, } \\
\text { highly mineralized }\end{array}$ & Cheder \\
\hline
\end{tabular}

Mud horizons have a monoclinal bedding, complicated by some asymmetry and the presence of local channel-like downsides, with maximum silt capacities concentrated in them and reaching a magnitude of $1.10 \mathrm{~m}$ in Lake Inder. Productive silt horizons are lined with compacted and viscous lake clays, loams and calves. Non-standard mud deposits clogged with sand, salt and regularly dried bands of deposits with a capacity up to $0.2 \mathrm{~m}$ are placed on productive lenses. Clay particles of silicate composition (up to $34.5 \%$ per dry substance) dominate in the crystal skeleton of mud in Lake Inder. The mud of Lake Alzhansor is soft, plastic, mass, having a weak smell of bitumen with the dense consistency and uniform structure. The mud of Lake Aralsor is light grey with the thick consistency, sour cream-shaped, heterogeneous structure and without smell. The mud of Lake Hakisor is brown with the thick consistency, knocked into a lump, uniform structure and odorless. The mud of Lake Sorkol is light grey with the thick consistency, plastic, with inclusions of sand and stones and without smell. The mud of Lake Bolshoy Sor is grey, with the thick consistency, plastic, without large inclusions and without smell. Their balneological value is determined by moisture capacity (natural humidity), consistency (shear resistance), degree of clogging by the large fractions, heat capacity and heat retention capacity, mineralization of mud solution, presence of hydrogen sulphide and iron sulphides, redox potential and medium reaction. The remaining values, such as heavy metals, limit concentrations that cannot be exceeded. Since the natural scattering of these elements is negligible and is usually safe for human habitation throughout its life a ten-fold excess is permissible in this case (Akhmedenov, 2019). According to the main physical and chemical indices, the mud of Lake Inder refers to the content of water-soluble salts in the mud solution (in $\mathrm{g} / \mathrm{l}$ ) - salinized (more than 150), the content of sulphides (FeS as a percentage of natural mud) - strongly sulphide (more than 0.50$)$, the reaction of medium ( $\mathrm{pH}$ ) weakly alkaline (7.0-9.0). According to the main physical and chemical indicators the mud of Lake Alzhansor refers to salinized strong sulphide, weakly alkaline mud, the mud of lakes Aralsor and Hakisor refers to salinized sulphide, weakly alkaline mud (Table 2). The mud of Lake Sorkol refers to the weakly sulphide weakly alkaline, and the mud of Lake Bolshoy Sor to the weakly sulphide highly mineralized. The requirements for the quality of therapeutic mud provide for such normative indicators, the non-conformity of which excludes the possibility of therapeutic use of peloids: humidity causes the consistency of the mud mass, which can only be plastic, retained on the patient's body and have high heat-retaining capacity at certain water content. Clogging with mineral particles or plant residues degrades the plasticity of the mud, and in the presence of large inclusions (crystals, fragments of shells, etc.) causes burns; shear resistance characterizes the plasticity of the mud procedural mass and hence its suitability for mud applications. Curative dirt or peloids can be used for various health-related practices (Ma'or et al., 2006; Munteanu and Dumitrascu, 2011; Gomes et al., 2013; Fioravanti et al., 2017). Indicators of humidity, clogging, shear resistance of the studied mud lakes Inder and Alzhansor meet the requirements for the quality of therapeutic mud (Table 2).

Table 2. Physical and chemical indicators of the West Kazakhstan mud

Data source: (personal original data, and also Akhmedenov et al., 2016a; Akhmedenov, 2019)

\begin{tabular}{|c|c|c|c|c|c|c|c|}
\hline Indicator & $\begin{array}{l}\text { Norm for sulphide-sludge } \\
\text { mud, units of measurement }\end{array}$ & Inder Mud & $\begin{array}{l}\text { Alzhansor } \\
\text { Mud }\end{array}$ & $\begin{array}{l}\text { Aralsor } \\
\text { Mud }\end{array}$ & $\begin{array}{l}\text { Hakisor } \\
\text { Mud }\end{array}$ & $\begin{array}{l}\text { Sorkol } \\
\text { Mud }\end{array}$ & $\begin{array}{l}\text { Bolshoy } \\
\text { Sor Mud }\end{array}$ \\
\hline Humidity & $25-75 \%$ & 26.1 & 47.3 & 35.2 & 23.1 & 27.9 & 40.1 \\
\hline Clogging with mineral particles d $0.25-5.0 \mathrm{~mm}$ & $\begin{array}{c}\text { no more than } 3.0 \\
\% \text { of natural substances }\end{array}$ & 2.99 & 2.99 & 6.45 & 0.78 & 20.7 & 1.06 \\
\hline Solid mineral inclusions $\mathrm{d}>5 \mathrm{~mm}$ & no, $\%$ of natural substances & no & no & no & no & no & no \\
\hline Sulphides (FeS) & $\begin{array}{c}\text { not less than } 0.01 \\
\% \text { from nat. substances }\end{array}$ & 0.55 & 0.56 & 0.47 & 0.15 & 0.02 & 0.04 \\
\hline Organic content & $\begin{array}{c}\text { not less than } 0.5, \\
\% \text { from nat. substances }\end{array}$ & 1.07 & 2.66 & 0.92 & 0.19 & 2.19 & 3.49 \\
\hline Shearing strength & $1.500-4.000$, dynes $/ \mathrm{cm}^{2}$ & 1640 & 4090 & 5440 & 31500 & 1990 & 3196 \\
\hline Content of water-soluble salts in mud solution & over $150, \mathrm{~g} / \mathrm{l}$ & 326 & 152 & 257 & 160 & 195 & 124 \\
\hline \multicolumn{8}{|l|}{ Heavy metals: } \\
\hline Zincum & \multirow{4}{*}{$\begin{array}{c}\text { Not more than natural } \\
\text { background, } \mathrm{mg} / \mathrm{kg}\end{array}$} & 31.5 & 26.9 & 25.0 & 26.3 & 8.02 & 42.8 \\
\hline Copper & & 10.0 & 8.9 & 7.52 & 7.7 & 2.54 & 15.2 \\
\hline Lead & & 49.7 & 38.7 & 7.13 & 0.1 & 12.4 & 15.5 \\
\hline Cadmium & & 1.82 & 1.34 & 2.79 & 3.0 & 1.65 & 1.31 \\
\hline
\end{tabular}


According to the indicators of mud clogging of Aralsor and Sorkol lakes and according to the indicator the resistance of mud shear of Hakisor Lake does not meet the quality requirements. The mud of Lake Bolshoy Sor does not meet the requirements for quality ( Table 2) by the content of water-soluble salts in the mud solution. As can be seen from the above data, the studied samples of therapeutic mud of Lake Inder and Alzhansor most meet the requirements for the treatment use. It should be said that the mud of Lake Alzhansor is characterized by a higher specific heat capacity, which is probably due to increased moisture content. According to the medical report of the Institute of Cardiology and Internal Diseases the highly mineralized mid-sulphide sludge of Lake Alzhansor can be used for medical purposes. Its mud is actively used by sanatoriums Akjayyk in West Kazakhstan region.

Not every person knows what specific diseases salty water and dirt helps. In the waters of Inder, people receive partial or complete healing in osteochondrosis, polyarthritis, rheumatism, skin diseases, neurosis, and a number of other diseases. Swimmin g in Lake Inder is possible for those who suffer from rheumatism, osteochondrosis, polyarthritis, skin diseases, neurosis, pancreatic diseases and women suffering from infertility. It is extremely dangerous to stay on the lake for those people having a high blood pressure, suffering a stroke, heart attack, suffering from kidney and liver diseases. Before visiting Lake Inder, it is recommended to undergo a medical ex amination and consult with doctors. The most favourable period for the mud treatment on Inder is the hottest time of the year: July and the beginning of August. It is best to visit Lake Inder before 11.00 in the morning and after $17.00 \mathrm{pm}$. It is not recommended to spend a long time in the mud; maximum 15-20 minutes and swim in the lake.

There is no appropriate infrastructure for the development of recreational and balneological tourism on the shores of these salty lakes. Huge investments are required to organize mud clinics. It should be a large-scale project at the state level. It is also difficult for a private entrepreneur to develop a full infrastructure on these salt lakes. But with the connection of gas, electricity and water to the locations of the lakes it may be possible to open boarding houses operating as medical institutions. It is necessary to develop recommendations for organized tourism and creation of treatment and preventive zones using mud of these lakes based on Kazakh and international experience (Yerdavletov, 2000; Vajčnerová, 2009; Backer and Ritchie, 2017; Nazarova et al., 2019; Valeyev et al., 2019).

\section{CONCLUSION}

The Haki mud has widespread fame among the local and remote population for its healing properties. The stocks of curative mud are inexhaustible. The location of the Haki mud near the Khan Orda village and the presence of pine boron in the vicinity create conditions for the opening of the mud resort here.

The reserves of therapeutic mud of Aschytuzbulak are very small; however, by carrying out a simple event it is possible to in crease them to the size that will be enough for a small mud resort. This will consist in the arrangement of subsoil in the lower part of the valley in such a way that the flat bottom of the valley is covered with a thin layer of rap. Then the processes of transformation will intensively occur on a large area, which will lead to an increase in the reserves of therapeutic dirt by several times.

On Lake Sorkol in the future it is possible to organize sports seasonal hunting for local and flight water game in permitted places. Sorkol Lake is also valuable as a body of water for amateur fishing of local importance and summer recreation.

Thus, comparative physical and chemical study of ground mud of the lakes Alzhansor, Aralsor, Hakisor, Sorkol, Bolshoy Sor in the West Kazakhstan region and Lake Inder in Atyrau region makes it possible to draw a conclusion on their compliance with the requirements for dirt for the medical use. The unique chemical composition of therapeutic mud in combination with rapeseed baths makes the above-mentioned lakes attractive for recreation of citizens of Kazakhstan and tourists from the neighbouring regions of Russia.

However, with all these favourable factors, sanitary and tourist activity on the six salt lakes studied is still marginal. Firstly, the lakes and surrounding landscape are still little developed. Secondly, the weak road network to the lakes and at the territory prevents significant touri sm development. In addition, there is no adequate infrastructure in these areas at the moment (hotels for rest, entertainment grounds, shops, cafes for food, etc.). The solution to this issue can be achieved by providing the market with high-quality competitive tourist products supported by correct social, economic and political actions to create treatment and entertainment complexes.

Awareness of the benefits from sanatorium and tourism activities in the socio-economic environment and its mediatisation will lead to the increased interest of people from different regions of Kazakhstan for the rest on the salty lakes of the region. Due to the high competition, it is possible to meet the needs of clients creating a sanatorium, tourist and recreational conditions (tourism with sports components, hotels and boarding houses, camp, leasing, guest houses, tourist residences and. While planning the development of tourist activities it is necessary to consider the following issues: provision of a competitive environment (establishment of a medical center for the treatment, prevention of health, development and construction of sports, health and entertainment complexes) with economic, ecological and socio-political stability; seasonal demand and integration between tourism and other economic activities; the impact of tourism activity on natural resources; decentralization of tourism revenues, actively involving the local population.

It is necessary to create a cluster in the West Kazakhstan focused on the creation of infrastructure of balneological treatment and health complex in the region of the studied lakes which in the future updates the previously untapped resource - therapeutic mud of the lake - and can create a new focus on tourist activity in the region. It is recommended to justify the economic efficiency and expediency of the construction of sanatorium-resort and medical-health tourist complexes which combine a wide range of medical-rehabilitation and touristhealth services. As a result, project products attractive to public and private investors are expected to be created.

\section{Aknowlegments}

This research was sponsored by the projects of Ministry of Education and Science of the Republic of Kazakhstan No. 4036/GF4 «Analysis of the social-economic importance of landscapes of salt dome for the Republic of Kazakhstan».

\section{REFERENCES}

Akhmedenov, K.M. (2018). The landscape and biological diversity of salt-dome landscapes: specific features (Western Kazakhstan case study). Arabian Journal of Geosciences, 11(15), 417. doi:10.1007/s12517-018-3725-x

Akhmedenov, K.M. (2019). Hydromineral resources of lakes of Western Kazakhstan. Bulletin of the West Kazakhstan State University, 3 , 440-452.

Akhmedenov, K.M., Petrishchev, V.P. \& Koshim, A.G. (2016b). Inder-the landscape geosystem of salt-dome origin. Al-Farabi KNU J Geogr ser., Almaty, 1(42), 5-9.

Akhmedenov, K.M., Petrishchev, V.P., \& Mukhsy, A.S. (2016a). Balneological assessment of medical mud of salt-and-alcohol structures of West Kazakhstan. Problems of Steppe Science, 13, 12-17.

Akhmedenov, K.M., Petrishchev, V.P., Abisheva, S.H., Bauedinova, G.K., \& Nugmanova, M.D. (2015). The springs and saline muds of the saltdome geosystems of Western Kazakhstan. Al-Farabi KNU J Geogr, Almaty, 2(41), 424-429.

Backer, E., \& Ritchie, B.W. (2017). VFR travel: a viable market for tourism crisis and disaster recovery? International Journal of Tourism Research, 19(4), 400-411.

Belenitskaya, G.A. (2013). The origin of Dead Sea salts, diapirs, and brines. Nature, 8, $28-37$. 
Carretero, M.I., Pozo, M., Legido, J.L., Fernández-González, M.V., Delgao, R., Gómez, I., Armijo, F., \& Maraver, F. (2014). Assessment of three Spanish clays for their use in pelotherapy. Applied clay science, 99, 131- 143. http://dx.doi.org/10.1016/j.clay.2014.06.022

Diarov, M.D., Kalacheva, V.G., \& Vescheryakov, S.V. (1981). Natural wealth of the Inder and its use, Alma-Ata: Science KazSSR, 136 p.

Egorina, A.V., Kaliakperova, N.Z., \& Kanatkyzy, N. (2016). Recreational opportunities of East Kazakhstan for tourism development. International Journal of Applied and Fundamental Research, 3, 298-302.

Egorov, A.N. (1993). Mongolian salt lakes: some features of their geography, thermal patterns, chemistry and biology. Hydrobiologia, 267, 13-21. doi:10.1007/bf00018788

Eisenstadt, G.E.-A., Pinchuk, I.A., \& Sokolova E.I. (1967). Jurassic deposits. Oil and gas-bearing thicknesses of the Caspian valley. Works of the All-Union Petroleum Research Geological Exploration Institute, 253. Leningrad, "Nedra" Publishing House, 41-109.

Fedorov, Y.A., \& Ruban, D.A. (2019). Geoheritage Resource of Small Mud Lakes in the Semi-Arid Environments of the Russian South. Resources, 8(2), 75.

Fedorov, Yu.A., \& Ruban, D.A. (2018). Peloids as important resource for regional sustainable development: Conceptual considerations. Espacios, 39(51), 21.

Filonets, P.P., \& Omarov, T.R. (1974). Lakes of North, West, East Kazakhstan. Guide. L., 3-47.

Fioravanti, A., Karagülle, M., Bender, T., \& Karagülle, M.Z. (2017). Balneotherapy in osteoarthritis: facts, fiction and gaps in knowledge. European Journal of Integrative Medicine, $9,148-150$

Gomes, C., Carretero, M.I., Pozo, M., Maraver, F., Cantista, P., Armijo, F., ... \& Delgado, R. (2013). Peloids and pelotherapy: Historical evolution, classification and glossary. Applied Clay Science, 75, 28-38.

Kan, S.M., Kalugin, O.A., \& Iskanderov, R.R. (2019). The importance of therapeutic muds of the Arasan-Kundyzdy deposit for the development of peloid therapy in Kazakhstan. Problems of Balneology, Physiotherapy, and Exercise Therapy, 96(6), 46-49.

Kapiki, S., Rakhmetulina, Z., \& Nurgaliyeva, A. (2014). Development of Tourism in the Republic of Kazakhstan. International Journal of Global Ideas, 2, 29-39.

Karagülle, M., \& Karagülle, M.Z. (2015). Effectiveness of balneotherapy and spa therapy for the treatment of chronic low back pain: a review on latest evidence. Clin Rheumatol, 34(2), 207-214. doi:10.1007/s10067-014-2845-2

Karakaya, M. Ç., Karakaya, N., Sarığlan, Ş., \& Koral, M. (2010). Some properties of thermal muds of some spas in Turkey. Applied clay science, $48(3)$, 531-537.

Kerimbay, B.S., Janaleyeva, K.M., \& Kerimbay, N.N. (2020). Tourist and recreational potential of landscapes of the specially protected natural area of Sharyn of the Republic of Kazakhstan. GeoJournal of Tourism and Geosites, 28(1), 67-79.

Korobov, S.S., \& Polenov, I.K. (1964). Karst of the one salt-and-water lifting of the Caspian valley. Hydrogeology of salt deposits and mineral waters. Leningrad, "Nedra" Publishing House, 84 - 97.

Kotov, S., Kotova, I., \& Kayukova, E. (2019). Geological controls and the impact of human society on the composition of peloids of present-day salt lakes (coastal zones of the Black, Azov, and Dead Seas). Journal of Coastal Conservation, 23(4), 843-855.

Kotova, I., Kayukova, E., \& Kotov, S. (2016). Peloids of Crimean salt lakes and the Dead Sea: controls on composition and formation. Environmental Earth Sciences, 75(16), 1207-1220.

Kutlusurin, Y.S. (2006). Characteristics of natural balneoresources of the Astrakhan region. The bulletin of the Astrakhan State Technical University, 6 (35), 83-88.

Ma'or, Z., Henis, Y., Alon, Y., Orlov, E., Sørensen, K. B., \& Oren, A. (2006). Antimicrobial properties of Dead Sea black mineral mud. International journal of dermatology, 45(5), 504-511.

Margaret, S.M., Nadia, M.V., Patricia, G.H., Clara, M.R., Josiel, B.C., Rebeca, H., ... \& Cristina, D. L. (2018). Physicochemical characterization, elemental speciation and hydrogeochemical modeling of Santa Lucía peloid used for therapeutic uses. Revista Internacional de Contaminacion Ambiental, 34, 105-110.

Matsumoto, S. (2018). Evaluation of the role of balneotherapy in rehabilitation medicine. Journal of Nippon Medical School, 85(4), 196-203.

Mocrinsky, V.V. (1938). Geological essay (stratigraphic section of deposits that form the Inder dome rise). Borates of the Inder. Moscow: State Joint Scientific and Technical Publishing House, 14-28.

Munteanu, C., \& Dumitrascu, M. (2011). Therapeutic muds. Balneo-Res. J., 2, 12-16.

Myazina, N.G. (2013a). Lake Caspian Basin her frame and their practical value. The bulletin of the Orenburg State University, 9(158), 115-118.

Myazina, N.G. (2013b). Comparison of hydrogeochemical features lake. Elton and the Dead Sea. Water management in Russia, 1, 52-59.

Nazarova, T.V., Fomin, I.A., Dmitriev, P.S., Wendt, J.A., \& Janaleyeva, K.M. (2019). Landscape and limnological research of lake systems of the plain areas of the northeastern borderlands of the Republic of Kazakhstan and assessment of their recreational capacity. GeoJournal of Tourism and Geosites, 25(2), $485-495$.

Neumann, L., Sukenik, S., Bolotin, A., Abu-Shakra, M., Amir, M., Flusser, D., \& Buskila, D. (2001). The effect of balneotherapy at the Dead Sea on the quality of life of patients with fibromyalgia syndrome. Clinical Rheumatology, 20(1), 15-19.

Petrishchev, V.P., \& Akhmedenov, K.M. (2017). Materials for creation of national park "Inder" in the Western Kazakhstan. Proceedings of the Russian State Hydrometeorological University. A theoretical research journal. St. Petersburg, 47, 187-192.

Posokhov, E.V. (1948). Therapeutic muds of Kazakhstan, Almaty, AS KazSSR, 31 p.

Razumov, A.N., Adilov, V.B., Davydova, O.B. Berezhnov, E.S., Bobrovnitsky, I.P., Gusarov, I.I., Dubovskaya, A.V., Zotova, V.I., Lvova, N.V., Novikova, O.V., Petrova, N.G., Rogovets, A.I., Seregina, I.F., Tereshkova, L.P., Trebuhov, Y.A., Trebuhova, T.M., Tupitsina, Yu.Yu. (2000). Classification of mineral waters and therapeutic mud for certification purposes. Guidelines No. 2000/34. Moscow, Russian Ministry of Health Publ. House, 150 p.

Rudenko, Y.I. (1975). Mineral water and therapeutic mud of the Lower Volga region, Volgograd, Nizh, Volzh, Book Publ. House, p. 72.

Sallam, E.S., El-Aal, A.K.A., Fedorov, Y.A., Bobrysheva, O.R., \& Ruban, D.A. (2018). Geological heritage as a new kind of natural resource in the Siwa Oasis, Egypt: The first assessment, comparison to the Russian South, and sustainable development issues. Journal of African Earth Sciences, 144, 151-160.

Saparov, K.T., \& Zhensikbayeva, N.Z. (2016). Evaluation of the Natural Resource Potential of the Southern Altai. Bulletin of D. Serikbayev East Kazakhstan State Technical University. Ust-Kamenogorsk, 3, 66-71.

Tatarinov, P.M. (1938). Borates of the Inder. Moscow State Joint Scientific and Technical Publishing House, 244 p.

Tokpanov, Y.A., Mukhitdinova, R.A., Alimbekov, Z.S., \& Berkinbayeva, Y.Y. (2019). The value of therapeutic mud of Karachaganak bay in the south-eastern part of Lake Balkhash for the development of health tourism and recreation. Science and world. International scientific journal, 1(65), 66-68.

Tserenkhand, B., Badnainyambuu, Z., Erdenechimeg, G., \& Bolormaa, O. (2018). Composition of water and peloid from lake Buuntsagaan and element acummulation of peloid. Journal of Chemical Technology and Metallurgy, 53(2), 258-266.

Vajčnerová, I. (2009). The quality of tourism destination - integrated quality management. Acta Univ. Agric. Silvic. Mendelianae Brun., 57, 6, $361-368$.

Valeyev, A.G., Abitbayeva, A.D., Mitrofanova, A.N., Halykov, Ye. Ye., Togys, M.M., Uxukbayeva, S.A., \& Sharapkhanova, Z.M. (2019). Recreation development potential of Lake Alakol. Issues of Geography and Geoecology, 3, 3-11.

Williams, W.D. (1991). Chinese and Mongolian saline lakes: a limnological overview. Hydrobiologia, 210, 39-66.

Williams, W.D. (1996). The largest, highest and lowest lakes of the world: Saline lakes, SIL Proceedings, 1922-2010, 26(1), 61-79.

Yang, B., Qin, Q.Z., Han, L.L., Lin, J., \& Chen, Y. (2018). Spa therapy (balneotherapy) relieves mental stress, sleep disorder, and general health problems in sub-healthy people. International journal of biometeorology, 62(2), 261-272.

Yegemberdiyeva, K.B., Karzhaubayev, K.K., Temirbayeva, R.K., Kelinbayeya, R.Z., Orazbekova, K.S., Khen, A.P. \& Yushina, Yu.A. (2018). Database creation tourist-recreational potential (on the example of the lakes in the Akmola region). Issues of Geography and Geoecology, 3, $10-18$.

Yerdavletov, S.R. (2000). Geography of Tourism: History, Theory, Methods, Practice, Text book, Almaty.

Zhensikbayeva, N.Z., Saparov, K.T., Chlachula, J., Yegorina, A.V., Uruzbayeva, N. A., \& Wendt, J. A. (2018). Natural potential for tourism development in Southern Altai (Kazakhstan). GeoJournal of Tourism and Geosites, 21(1), 200-212.

Zhensikbayeva, N.Z., Saparov, K.T., Kulzhanova, S.M., ATASOY, E., \& Wendt, J. A. (2017). Determination of Southern Altai geography propitiousness extent for tourism development. GeoJournal of Tourism and Geosites, 20(2), 158-164. 